\title{
A Greenhouse Gas Emissions Inventory and Ecological Footprint Analysis of Metro Vancouver Residents' Air Travel
}

\author{
Ruth Legg ${ }^{1}$, Jennie Moore ${ }^{1}$, Meidad Kissinger ${ }^{2} \&$ William Rees ${ }^{1}$ \\ ${ }^{1}$ School of Community and Regional Planning, University of British Columbia, Vancouver, BC, Canada \\ ${ }^{2}$ Department of Geography and Environmental Development, Ben-Gurion University of the Negev, Beer-Sheva, \\ Israel \\ Correspondence: Jennie Moore, School of Community and Regional Planning, University of British Columbia, \\ Vancouver, BC, Canada. Tel: 1-778-928-2207. E-mail: jennielynnmoore@hotmail.com
}

Received: July 15, 2013 Accepted: September 16, 2013 Online Published: September 27, 2013

doi:10.5539/ep.v2n4p123 URL: http://dx.doi.org/10.5539/ep.v2n4p123

\begin{abstract}
Ecological Footprint Analysis (EFA) at the city or regional scale does not typically include air travel due to a lack of readily available data. However, knowing the "load" placed on nature by various lifestyle choices, including air travel, is essential if we hope to enable society to live sustainably within ecological limits. This paper provides methods for including air travel in urban EFA, in a manner that is accessible to those that are interested in the complexities of urban sustainability. Our goal is to use the case of the Vancouver Metropolitan region to illustrate two methods in such a way that they can be replicated or adapted for use in other cities and regions. We found that the greenhouse gas emissions of air travel by Metro Vancouver residents for 2006 is between 1,191,070 and 1,402,420 tonnes of carbon dioxide equivalent $\left(\mathrm{tCO}_{2} \mathrm{e}\right)$. The resulting ecological footprint is between 287,030 and 337,980 global hectares (gha), or between 0.136 and 0.160 gha/capita. The dedicated carbon sink required to neutralize the carbon dioxide emissions from Metro Vancouver residents' air travel alone is equivalent to twice the land area of the region (283,183 hectares).
\end{abstract}

Keywords: air travel, climate change, ecological footprint analysis, greenhouse gas emissions, methods, Metro Vancouver, peak oil, regional planning

\section{Introduction}

Demand for air travel and its ecological impacts should be scrutinized if society is to respond effectively to climate change, (Union of Concerned Scientists, 1992; Rees, 2008). According to the International Civil Aviation Organization (ICAO), global air passenger travel has been increasing at an annual rate of approximately $7 \%$ over the past decade with concomitant increases in greenhouse gas emissions (ICAO, 2011). In 2010, the ICAO established environmental objectives to limit greenhouse gas emissions from air travel and committed to developing a carbon dioxide emissions standard for aircraft (Benjamin, 2013). The ICAO also established a global annual fuel efficiency target of $\%$ per year to 2020 (Benjamin, 2013). Nevertheless, helping local governments and their citizens to understand their role in driving demand for air travel and the 'load' placed on nature by various lifestyle choices, including air travel, is also essential to enable society to live sustainably within ecological limits.

A greenhouse gas emissions inventory (GHG) measures the quantity of emissions associated with particular activities. Data from GHG emissions inventories can be used to inform ecological footprint analyses. An ecological footprint (EF) measures the amount of ecologically productive land and sea area required to supply the demand of a given population at its current level of affluence and technology (Rees, 1992; Wackernagel \& Rees, 1996). Combining the two approaches can provide important feedback about demand on nature's services relative to global waste sink capacities.

Globally, cities and regions provide important leverage points for policy/programs designed to help people live within ecological limits. Ecological footprint analysis (EFA) can help local and regional governments communicate the ecological impacts of lifestyle choices and compare an urban populations' demands for biocapacity with locally and globally available supplies. In particular, understanding how these demands are distributed among commodity and waste flows through a city's or region's economy can inform strategic 
decision-making and provide a framework for setting goals, collecting data, and monitoring progress. EFA can also illuminate local/regional anomalies by enabling comparisons with other regions. While the method is still being refined, EFA is increasingly being applied in sustainability programs at the city and regional level (City of Vancouver, 2011; Kuzyk, 2011; Graymore, 2010; Wilson \& Grant, 2009; McManus \& Grant, 2006; Muniz \& Galindo, 2005; James \& Desai, 2003; Lewan \& Simmons, 2001).

One major source of GHG emissions traceable to affluent urban populations is air travel. To date, while various researchers acknowledge its importance (e.g., Barrett, Vallack, Jones, \& Haq, 2002; Wilson \& Anielski, 2005), only a few out of dozens of published urban EFA studies have measured the air travel component, and these mostly use national data or economically derived input-output data with limited transparency of method and data sources (e.g., Collins, Flynn, Wiedmann, \& Barrett, 2006; Aall \& Norland, 2005; Xu \& San Martin, 2010).

The purpose of this paper is to demonstrate a method to include air travel in urban EFA. Specifically, we estimate the GHG emissions and EF of air travel by residents of Metro Vancouver, Canada, over a one-year period (2006).

\subsection{Air Travel, Climate Change and Ecological Limits}

Canadians travel now more than ever. The total number of passengers through Vancouver's International Airport (also recognized by its call letters YVR) increased by 63\% from 9,935,285 in 1992 to $16,177,438$ in 2009 (Vancouver International Airport Website, 2010). Airport marketing and environmental department staff estimate that approximately $29 \%$ of this volume can be attributed to travel by Metro Vancouver residents (Frisby, personal communication, December 1, 2010). As a sector, Transportation contributed $37 \%$ of the growth in Canada's GHG emissions from 1990 to 2008 (National Inventory Report, 2010). While the impact of aviation's emissions is relatively minor within the entire transportation sector (4\% of emissions in 2006), air travel's impact with regard to climate change is significant for two reasons. First, aircraft emissions affect the climate system differently than other forms of transportation because they are usually generated at high altitudes. Here, according to the Intergovernmental Panel on Climate Change (IPCC) they catalyze chemical reactions that enhance radiative forcing (IPCC, 2001a, 2001b). According to the David Suzuki Foundation (DSF), the net impact of aircraft emissions on climate change is 2-4 times that of comparable carbon dioxide emissions at lower altitudes (DSF, 2010). As a result, the per passenger kilometer impact of air travel is greater than that of other forms of transportation, including busses and trains (DSF, 2010). Second, airfares do not reflect either market or ecological costs. For example, over the five-year period from 2002/03 to 2006/07, the Canadian Government provided direct subsidies, grants and contributions to air travel totaling over $\$ 240 \mathrm{M}$ (Transport Canada, 2006) which compensated for rising fuel costs. This inflates demand for air travel and, with it, attendant GHG emissions and their contribution to the unaccounted costs of climate change.

\subsection{Peak Oil and Globalization}

Petroleum is needed to power air travel but there is a widening gap between supply and potential demand for oil globally (Hall \& Day, 2009). Since 2010, approximately 1,500 commercial flights have utilized biofuels (Hupe, 2013); nevertheless, it is unknown whether alternatives to fossil fuel could sustain the current rate of air travel. The National Aeronautics and Space Administration (NASA) indicates that alternatives to fossil fuel "have good potential but presently appear to be better suited for use in ground transportation" (Daggett, 2006, p. 1).

There may soon be significant supply/price problems. Even the International Energy Agency (IEA) has publicly recognized that the global rate of conventional oil extraction peaked in 2006 and is now in decline (IEA, 2010). Recent enthusiasm over potentially abundant supplies of 'tight' oil (e.g., shale-oil in the US) overlooks the low energy-returns-on-energy-invested (EROEI) and rapid depletion rates of shale oil discoveries. In sum, declining fossil fuel reserves may well soon constrain future air travel.

Limited resource availability and waste absorption capacity highlight the importance of knowing the extent to which air travel contributes to urban populations' GHG emissions and ecological footprints. These data will enable more informed decisions about air travel relative to other modes of transportation and competing demands for petroleum.

\subsection{Metro Vancouver Background}

Located in the southwest corner of British Columbia, Canada near the United States (US) border, Metro Vancouver is home to approximately 2.3 million people and spans an area of 283,183 hectares (Metro Vancouver, 2006). It comprises 22 municipalities, including the City of Vancouver, and includes both urban and peri-urban environments (Metro Vancouver, 2011). The region contains some of Canada's most fertile agricultural land; the delta of one of Canada's largest rivers, the Fraser River; forested mountains; and coastal shores with several 
commercial fisheries. The region's main economic activities include: business services, tourism, manufacturing, and agriculture (BC Stats, 2010). Professional, technical and other services, such as public administration, retail trade and construction, comprise the majority of business employment (BC Stats, 2010).

Although recognized in the literature for its commitment to advancing sustainability through regional plans and initiatives (Pivo, 1996; Holden, 2006; Newman \& Jennings, 2008; Wheeler \& Beatley, 2009), Metro Vancouver is fairly typical of a high-consuming, first-world, urban region (Rees, 2009; Berelowitz, 2005). In 2006, the average income was $\$ 40,252 \mathrm{Cdn}$, with a labour-force participation rate of $67 \%$. Household median income was $\$ 69,688$, and the majority of households, $65 \%$, owned their own home despite exceedingly high housing costs averaging \$520,937 Cdn. Fifty-seven percent of the region's population is between 25 and 64 years of age and $62 \%$ of this group have some type of post-secondary education credential (BC Stats, 2010).

Regional transportation services are managed by the Greater Vancouver Transportation Authority (GVTA), also known as TransLink. This is a sister agency to Metro Vancouver that is operated jointly by Metro and the Province of British Columbia. Of particular significance to this study is the Vancouver International Airport, also known by its airport code, YVR (Note 1). The airport is situated within the Fraser River Delta, and also within the Pacific Flyway for migrating birds. It serves as Canada's air travel gateway to the Pacific and represents an important travel link for both Canadian and international business and tourist travelers.

\section{Method}

\subsection{Ecological Footprint}

Many studies have estimated the $\mathrm{CO}_{2}$ emissions of air travel, and have described various methods for apportioning greenhouse gas emissions to air travel. Wood, Bows and Anderson (2010), for example, categorize the range of aviation greenhouse gas-apportioning methods by two filters - the emissions-allocation approach (involving local producers or consumers) and the emissions accounting method. In the former method, the "producer" variation involves estimates based on plane landings and take-offs; the "consumer" variation generates estimates that are based on passenger and freight data. The more top-down emissions-allocations approach employs national data accounts (e.g., such as those used by the Global Footprint Network to develop the National Footprint Accounts) combined with input-output multipliers. Wood et al. (2010) present a general framework but do not actually describe how to calculate GHG emissions. Our study describes two methods in detail, showing the step-by-step calculations, in order to make the methods accessible to planning practitioners and others at the community level interested in incorporating air travel in EFA.

While some report that the primary strength of EFA is as a communication tool (Weidman \& Barrett 2010), it also has potential as a policy tool even at the local (municipal) level, particularly given growing interest in "one-planet living". The latter concept uses EFA as a primary metric (e.g., City of Cardiff, 2012; City of Vancouver, 2011; Desai, 2008). That said, three criticisms of EFA are relevant to this study. First, some analysts question the method's focus on GHGs, specifically carbon dioxide emissions to express waste (Fiala, 2008; Nijkamp, Rossi, \& Vindign, 2004; Ayers, 2000; Van den Bergh \& Verbruggen, 1999). Second, some researchers are concerned that EFA lacks transparency and that the required data are unavailable (Wilson \& Grant, 2009; Aall \& Norland, 2005). Third, critics argue that local governments lack the capacity to do EFA and that this undermines its relevance to planning practitioners (Curry, Maguire, Simmons, \& Lewis, 2011; Wilson \& Grant, 2009; Aall \& Norland, 2005).

Let us take these points in order. We justify the focus on carbon dioxide emissions in EFA on several grounds: first, carbon dioxide emissions are the single largest waste product by weight in developed countries and increasingly in emerging economies; second, carbon dioxide is part of the natural carbon cycle and, because it is assimilated by growing plants, it can readily be represented by a corresponding exclusive (Note 2) area of productive ecosystems (e.g., carbon sink forest). Most other industrial wastes are not translatable into the eco-footprint metric. Third, carbon dioxide is the primary anthropogenic greenhouse gas and must be reduced to avoid excessive global warming. To date, the only practical means of re-absorbing atmospheric $\mathrm{CO}_{2}$ is through natural or intentionally-created, dedicated carbon sink ecosystems and EFA provides an accurate estimate of the required ecosystem area. Finally, inclusion of carbon emissions in EFA is useful in policy discussions involving the public because an area-based carbon footprint is a graphically explicit link "between human consumption and [demand for] ecosystem services" (Weidman \& Barrett, 2010, p. 1649). (N.B. Other tools are available to quantify and assess the impacts of other forms of waste, many of which are already being used by local governments.)

The second and third criticisms are not so much faults with EFA per se as they are comments on society's prevailing understanding of humankind-ecosystem interactions (which are indeed complicated and somewhat 
opaque) and with our corresponding perceptions of data requirements for sustainability planning. To the extent that EFA can contribute to developing that understanding and to balancing human demand with the supplies of ecosystems services, municipal data collection should be adapted to facilitate the analysis. In fact, using locally derived data contributes to methodological transparency and confidence because much of the data required to generate an EFA can be, or is already being, used for other policy and planning purposes in the community (e.g., waste management). Where local databases are not yet sufficiently sophisticated for EFA it is possible to adapt national production and consumption data to reflect local energy and material consumption- local data bases and EFA are still co-evolving (Wackernagel, 2009).

The objection that local governments often lack analytic capacity to do EFA may be true but, again, speaks more to the need for new forms of training for municipal planners, engineers and technicians than to a weakness in EFA. As society comes to recognize the reduction of energy and material throughput as key to sustainability, skills in such related methods as material flows analysis, life cycle analysis and eco-footprint analysis will become essential to municipal planning and management.

In the present study, we rely on publicly available local data and describe all steps in detail.

\subsection{Air Travel by Metro Vancouver Residents}

To estimate the GHG emissions and ecological footprint of air travel by Metro Vancouver residents, we collected data from several sources and organized them into three flight categories: international, domestic (national), and commuter (intra-provincial). All data are for the 2006 calendar year, January to December as this was the year with the most widely available data and coincides with Canada's national census. Seven steps in data collection and analysis are outlined below with notes on differences in data quality among flight categories.

\subsubsection{Passenger Movements}

Data from our two main sources, the Vancouver International Airport (YVR) and Statistics Canada's air travel survey, generated different estimates of passenger movements (Note 3). We therefore present a range of GHG emissions and corresponding carbon eco-footprint estimates.

\subsubsection{Estimates Based Mainly on YVR Data (Approach “A”)}

This study required data on the number of passengers on outbound flights originating in YVR sorted by destination. For international flights to the United States (US), we retrieved data from Statistics Canada (2006a) on the number of passengers flying from Canada to the US by origin and destination. We then grouped data on flights originating in YVR into eleven different destination regions as defined in the International Travel Survey (2008), "Canadian Resident Trips Abroad". We recorded the most frequented airport in each of the eleven regions. For all other international flights, YVR (2010) provided data on the number of international outbound flights by destination. We classified these data by destination into five regions (Africa, Asia-Pacific, Europe, Latin America-Caribbean and the Middle East) and recorded the most frequented airport for each region. For domestic and commuter flights, YVR provided data on the number of outbound flights by destination (YVR, 2010).

\subsubsection{Distance Traveled}

To estimate passenger miles traveled we determined the Great Circle Distance (Note 4) between YVR and the most frequented destination airports in each region (identified from the International Travel Survey 2008), "Canadian Resident Trips Abroad", using the World Airport Codes (2010) web tool. This step is the same for all categories of travel: international, domestic and commuter.

\subsubsection{Aircraft Information}

We compiled data on the aircraft type, passenger capacity, average load factor and mileage for flights to each destination. YVR (2010) provided information on typical aircraft employed. We used an average load factor of $80 \%$ seat occupancy as cited in the National Greenhouse Gas Inventory Report (Environment Canada, 2010) (Note 5). Sources for passenger capacity and mileage differ by category. For international and domestic flights, we used Aircraft Charter World (Air Broker Center International, 2009) to determine passenger capacity for each aircraft and the Research and Innovative Technology Administration (RITA) Bureau of Transportation Statistics (2010) to determine the mileage (passenger miles per gallon) for each aircraft. Where we had data on the number of flights only we estimated passenger numbers on outbound flights by using the $80 \%$ average load factor (Environment Canada, 2010). While some data sources used imperial measurements, we converted our final calculations into metric.

For commuter flights, we used OAG Aviation (2010) and Airliners.net (2010) to determine passenger capacity 
for each aircraft, then converted number of flights to number of people on outbound flights by multiplying flights by passenger capacity - with an $80 \%$ average load factor (Environment Canada, 2010). We used the RITA Bureau of Transportation Statistics (2010) estimates of mileage (passenger miles per gallon) for most of the commuter aircraft. For mileage data not available on RITA, we used data from the Transportation Safety Board of Canada (2010); Airliners.net (2010); UK Department of Transport (2010); and All Experts Encyclopedia (2010) on gallons per hour fuel consumption rates. To convert gallons per hour to gallons per passenger, we consulted Kayak Flight Finder (2010) to find hours per one-way flight, multiplied gallons per hour by number of hours per one-way flight to find gallons of fuel consumed, then divided gallons of fuel consumed per flight by estimated passenger load to find gallons of fuel consumed per passenger.

\subsubsection{Fuel Consumption}

We calculated the total fuel consumed from outbound air travel originating in YVR in gallons, and then converted to Liters (L), using the standard conversion of $3.78541178 \mathrm{~L}$ per gallon (Quinn, 1996) (Note 6).

For international and domestic flights, we calculated gallons of fuel consumed per passenger by dividing distance (miles) by mileage (passenger miles per gallon). Second, we calculated total fuel consumption by multiplying the number of people on outbound flights from YVR by gallons of fuel consumed per passenger. We followed the calculations above for most of the commuter flights, but where we calculated fuel consumed per passenger (instead of passenger miles per gallon), we multiplied gallons of fuel consumed per passenger by number of people on outbound flights to find total fuel consumed.

\subsubsection{Scale for Residents}

Marketing research undertaken by YVR reveals that approximately $29 \%$ of passengers boarding flights are Metro Vancouver residents (YVR, 2010). We therefore estimated total fuel consumption by Metro residents by doubling the aggregate fuel consumption on all outbound flights to account for return flights, and multiplying by 0.29 to scale for flights by residents. This step is the same for all categories. (For Approach B, see section 2.8 below.)

\subsubsection{Greenhouse Gas Emissions}

We then calculated the GHG emissions $\left(\mathrm{CO}_{2}, \mathrm{CH}_{4}\right.$ and $\left.\mathrm{N}_{2} \mathrm{O}\right)$, and the $\mathrm{CO}_{2}$ equivalent $\left(\mathrm{CO}_{2} \mathrm{e}\right)$ for non- $\mathrm{CO}_{2}$ emissions, using emission factors from Environment Canada's National Greenhouse Gas Inventory Report (Environment Canada, 2010) and $\mathrm{CO}_{2} \mathrm{e}$ conversion factors obtained from Natural Resources Canada (Leblanc personal communication November 9, 2010). All units were converted from grams $(\mathrm{g})$ to tonnes $(\mathrm{t})$ by dividing by $10^{6}$. For international and domestic flights, we used emission factors, in grams per $\mathrm{L}$ for aviation turbo fuel, to complete the following equations: $\mathrm{L}$ fuel burned $\times 2,534=\mathrm{g} \mathrm{CO}_{2}$ emitted; $\mathrm{L}$ fuel burned $\times 0.080=\mathrm{g} \mathrm{CH}_{4}$ emitted; $\mathrm{L}$ fuel burned $\times 0.23=\mathrm{g} \mathrm{N}_{2} \mathrm{O}$ emitted.

We then used conversion factors for $\mathrm{CH}_{4}$ and $\mathrm{N}_{2} \mathrm{O}$ to calculate the $\mathrm{CO}_{2} \mathrm{e}$ for $\mathrm{CH}_{4}$ and $\mathrm{N}_{2} \mathrm{O}$ through the following equations: $\mathrm{CH}_{4}$ emitted $\times 21=\mathrm{CO}_{2} \mathrm{e} ; \mathrm{N}_{2} \mathrm{O}$ emitted $\times 310=\mathrm{CO}_{2} \mathrm{e}$ (Note 7).

For commuter flights, we followed the steps above for all aircraft using aviation turbo fuel. For aircraft using aviation gasoline, we used the following emission factors (conversion factors same as above): $\mathrm{L}$ fuel burned $\times$ $2342=\mathrm{g} \mathrm{CO}_{2}$ emitted; $\mathrm{L}$ fuel burned $\times 2.2=\mathrm{g} \mathrm{CH}_{4}$ emitted; $\mathrm{L}$ fuel burned $\times 0.23=\mathrm{g} \mathrm{N}_{2} \mathrm{O}$ emitted.

\subsubsection{Ecological Footprint}

Last, we calculated the ecological footprint of all air travel by Metro Vancouver residents. Since only carbon dioxide is sequestered by ecosystems, our estimate of the ecological footprint of air travel is based on only the carbon dioxide emissions. We follow the protocol established by the Global Footprint Network (Ewing et al., 2008) for calculating the "Energy Land" meaning the dedicated carbon sink lands required to sequester carbon dioxide emissions, based on annual average global terrestrial sequestration capacity (Ewing et al., 2009). A simplified equation is:

$$
\mathrm{EFc}=\left(\mathrm{tCO}_{2 \text { Air Travel }}\left(1-\mathrm{S}_{\text {ocean }}\right)\right) / \mathrm{Yc} \times \mathrm{EQF}
$$

Where $\mathrm{EFc}$ stands for carbon sequestration land, $\mathrm{tCO}_{2}$ is the weight of carbon dioxide emissions resulting from fuel combustion associated with Metro Vancouver residents' air travel, $\mathrm{S}_{\text {ocean }}$ represents the proportion of carbon dioxide sequestered by the world's oceans, and $\mathrm{Yc}$ is the annual rate of carbon sequestered per hectare of forest land (assuming world average yields). EQF is the equivalence factor prescribed by the Global Footprint Network (Ewing et al., 2009) used to convert global average yield for forest land to global average yield for all land types.

Specifically, since approximately $26 \%$ of carbon emissions are absorbed by the oceans, (IPCC, 2001c; Wackernagel \& Monfreda, 2004; Scotti, Bondavalli, \& Bodini, 2009; Kitzes \& Wermer, 2006); the $\mathrm{S}_{\text {Ocean }}$ is equal 
to 0.26 and we subtract this proportion from the total emissions associated with Metro air travelers. We then convert the remaining emissions into the equivalent area of carbon sink forest, assuming a global average assimilation rate of 3.7 tones carbon dioxide (1.0 tone carbon) per hectare of forest (Scotti et al., 2009; Kitzes \& Wermer, 2006). Finally, this forest area was multiplied by an equivalence factor of 1.24 (EQF) to represent the carbon sink in gha (reflecting the fact that forests are more productive than world average productive land (Ewing et al., 2009; Kitzes \& Wermer, 2006).

\subsubsection{Statistics Canada Air Travel Survey (Approach "B”)}

Based on YVR data, in approach A, we assumed that $29 \%$ of the people flying from YVR are Metro Vancouver residents and applied this ratio to flights to all destinations (international, domestic and commuter). This may be problematic. We therefore offer an alternative to the $29 \%$ blanket scaling method using data from a Statistics Canada travel survey on the travel patterns of BC residents classified by destination (Statistics Canada, 2006b). Aside from scaling, all other steps remain the same. We apply this alternative method to international and domestic flights, but not to commuting flights for lack of data. (Here we fall back on the original $29 \%$ scaling method.)

One shortcoming of this approach is that the Statistics Canada survey focused on the whole province, not just Metro Vancouver. We therefore estimated GHG emissions per BC resident and multiplied this by the Metro Vancouver population to obtain the required sub-sample. If anything, this probably underestimates actual emissions. Over $60 \%$ of $\mathrm{BC}$ residents live in Metro Vancouver, and socioeconomic data suggest that their share of overall $\mathrm{BC}$ travel is probably higher than the provincial average.

\subsection{Limitations and Assumptions}

As explained above, the study was constrained by cases of poor data which forced the use of informed estimates and by the need for certain methodological assumptions.

Two important data gaps were due largely to systemic and time/resource limitations respectively. First, YVR could provide data only on flights to first destinations. The lack of information on connecting flights could be a significant omission. Second, we were unable to account for Metro Vancouver residents who may drive to airports in close proximity to YVR such as Bellingham, Washington or Abbotsford, BC. Not including connecting flights or flights from nearby airports results in conservative estimates of Metro residents total air travel emissions.

One key assumption, that Metro Vancouver residents account for $29 \%$ of total outbound flights to all destinations, introduced the possibility of significant error and inspired an alternative estimate based on a Statistics Canada travel survey that included final destinations. Thus, our initial estimate using only YVR data treats a trip to Europe through Toronto as a flight to Toronto while the Statistics Canada data enabled us to document the entire journey to Europe. Developing this alternative approach enabled us to provide a plausible range of GHG emissions by Metro Residents.

Other emissions that also contribute to climate change, such as water vapor, are not quantified. Further, our estimates do not control for a variety of other factors that affect fuel consumption: type and age of engine(s) used in the airplane; weight; weight distribution; flight path factors such routing and distance flown; take-off and landing requirements of airports; and environmental factors such as wind speed and direction, temperature, altitude and air pressure. Keep in mind too that load factors are continually shifting as newer planes with improved fuel economy are introduced.

\section{Results}

We found that the GHG emissions from air travel by Metro Vancouver residents in 2006 were between 1,191,070 and $1,402,400 \mathrm{tCO}_{2} \mathrm{e}$ including $1,157,380$ to $1,362,810$ tonnes of carbon dioxide. By comparison, total GHG emissions from on-road transportation within the region were 5,386,785 $\mathrm{tCO}_{2} \mathrm{e}$, of which 4,505,287 $\mathrm{tCO}_{2} \mathrm{e}$ was from light duty vehicles (Metro Vancouver, 2007) (Note 8). Therefore, GHG emissions from air travel represent an additional $26 \%$ to $31 \%$ of GHG emissions that could be attributed to personal travel by Metro Vancouver residents, or $22 \%$ to $26 \%$ considering the on-road transportation sector as a whole. While Metro Vancouver does not include air travel emissions beyond those from takeoff and landing in its GHG emissions inventory (Metro Vancouver, 2007), it does identify collaboration with senior government agencies (e.g. Environment Canada and Transport Canada) as important to effective emissions management. Such collaboration on managing GHG emissions from air travel may become necessary to fulfill Metro Vancouver's goal of becoming a sustainable region (Metro Vancouver, 2005).

We found that the ecological footprint of air travel by Metro Vancouver residents for 2006 is between 287,030 
and 337980 gha (Table 1). This is the area of productive terrestrial ecosystems (carbon sink forest) that would be required on a continuous basis to assimilate the typical annual $\mathrm{CO}_{2}$ emissions of Metro Vancouver residents' air travel and is between $99 \%$ and $116 \%$ the size of the region's geographic land area (290 462 ha). Nevertheless, this underestimates the total ecological impact because it does not account for other GHG emissions that contribute to climate change such as $\mathrm{CH}_{4}, \mathrm{~N}_{2} \mathrm{O}$ and $\mathrm{H}_{2} \mathrm{O}$ (See Table 1 for all GHGs - except water vapor-in $\mathrm{CO}_{2}$ equivalents for both analytic approaches).

Table 1. Metro Vancouver's 2006 air travel greenhouse gas emissions and ecological footprint

\begin{tabular}{ccccccc}
\hline Flight Type & $\begin{array}{c}\mathrm{CO}_{2} \mathrm{e} \\
\text { Approach } \\
\text { "A" }\end{array}$ & $\begin{array}{c}\mathrm{CO}_{2} \mathrm{e} \\
\text { Approach } \\
\text { "B" }\end{array}$ & $\begin{array}{c}\mathrm{CO}_{2} \\
\text { Approach } \\
\text { "A" }\end{array}$ & $\begin{array}{c}\mathrm{CO}_{2} \\
\text { Approach } \\
\text { "B" }\end{array}$ & $\begin{array}{c}\text { EFA } \\
\text { Approach } \\
\text { "A" }\end{array}$ & $\begin{array}{c}\text { EFA } \\
\text { Approach } \\
\text { "B” }\end{array}$ \\
\hline tonnes & tonnes & tonnes & tonnes & $\begin{array}{c}\text { global } \\
\text { hectares }\end{array}$ & $\begin{array}{c}\text { global } \\
\text { hectares }\end{array}$ \\
\hline Domestic & 393,650 & 251,180 & 382,630 & 244,150 & 94,890 & 60,550 \\
\hline Commuter & 53,450 & 53,448 & 51,600 & 51,600 & 12,800 & 12,800 \\
\hline Total & $1,191,070$ & $1,402,420$ & $1,157,380$ & $1,362,810$ & 287,030 & 337,980 \\
\hline
\end{tabular}

Table 1 reveals that for Approach A, international air travel accounts for by far the biggest portion of emissions among the three categories (international, domestic, commuter), comprising $63 \%$ of the total air travel footprint. Domestic travel takes second place, at $33 \%$ of the total. Commuter travel is a fairly small portion of the total, at just 4\%. For Approach B, international travel accounts for an even larger share at 78\% of the total travel footprint. Domestic travel trails in second place at 18\%, and commuter emissions are negligible at less than $1 \%$.

The table also shows that analysis using the Statistics Canada survey data (Approach 'B') produces an EF 15\% larger than that derived from YVR's more limited data.

Figure 1 ( $a$ and $b$ ) breaks down Metro Vancouver air travel GHG emissions by specific destinations for both calculation procedures and shows there are considerable differences between them. For example, according to YVR data (Approach A) approximately 43\% of GHG emissions were associated with flights to Asia. The Statistics Canada survey data produced a corresponding number of only $21 \%$. Similarly Approach A suggests that flights to Europe account of $15 \%$ of GHG emissions while Approach B associates 23\% of GHG emissions to European destinations.

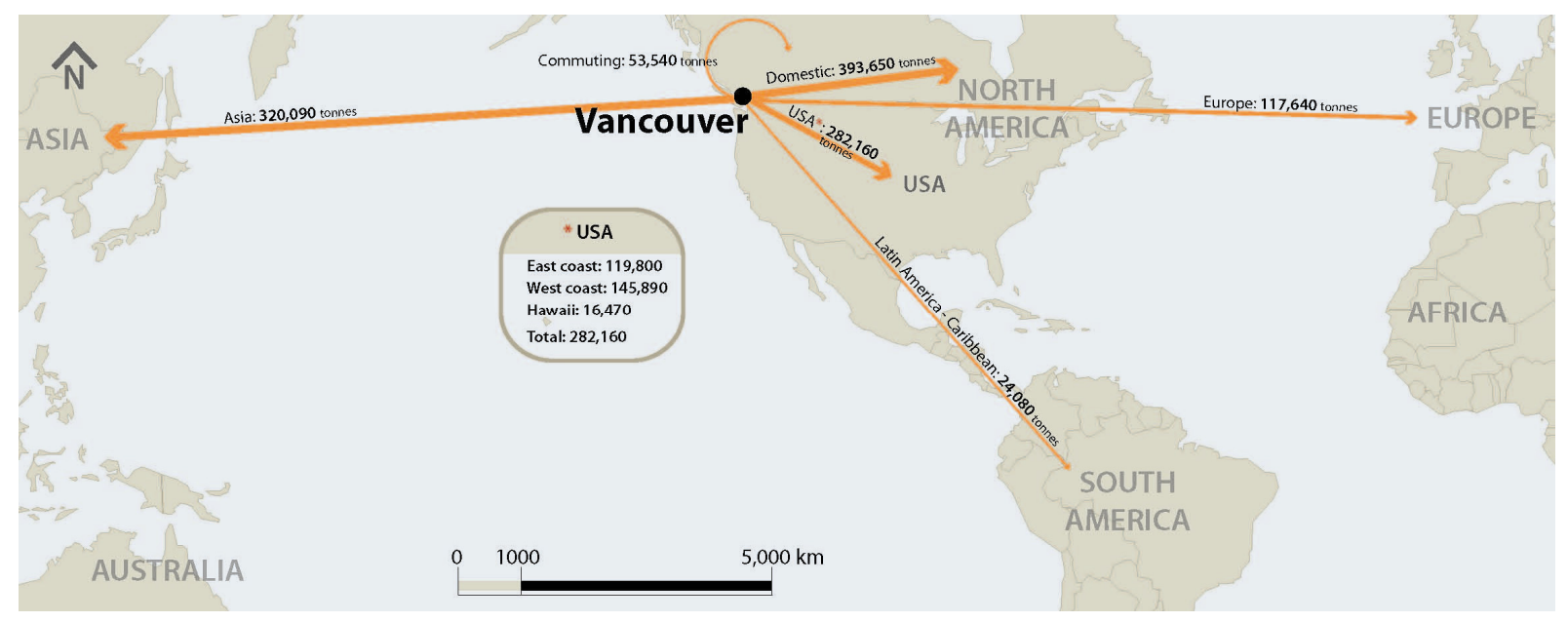

Figure 1a. Metro Vancouver air travel GHG emissions by destination, Approach "A" 


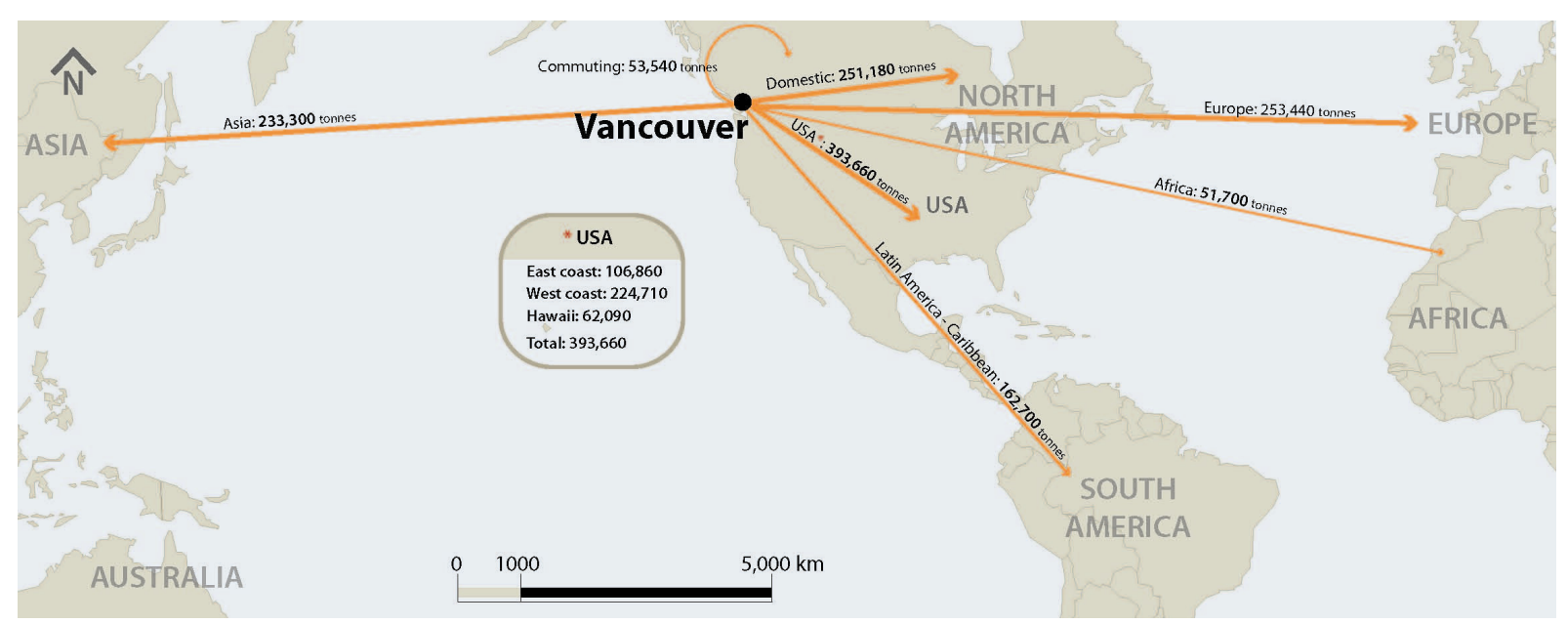

Figure 1b. Metro Vancouver air travel GHG emissions by destination, Approach "B"

\section{Discussion}

Through the use of two different methods described above, we have demonstrated how to estimate the GHG emissions and ecological footprint of air travel by residents of Metro Vancouver for a typical one-year period (2006). The main finding is that in 2006, the residents of Metro Vancouver relied on a productive land area larger than the region itself to meet their carbon sink demands from air travel.

A major strength of eco-footprinting is that it enables graphic comparisons of human demand for biocapacity with available supply. Our results show that, even if it were fully covered in healthy growing forest, the entire Metro Vancouver region would provide insufficient biocapacity to assimilate the carbon emissions from residents' air travel alone (and we would still have to account for all other carbon emissions). Metro Vancouver is clearly running a massive ecological deficit (Note 9) of which demand for carbon assimilation capacity is a major component. Such results underscore the extent to which wealthy high-income regions off-load their biophysical demands onto other regions and the global commons, the unspoken assumption being that there is surplus capacity 'elsewhere' to cover these regional deficits. The steady accumulation of carbon dioxide in the atmosphere shows this not to be the case. It follows that reducing the demand for air travel by Metro Vancouver residents or otherwise finding ways to mitigate air travel's ecological impacts could become increasingly important goals for a would-be sustainable region, given finite ecological resources and waste assimilative capacities and a lack of suitable technology to substitute for fossil fuels.

Although GHG emissions from air travel fall outside the jurisdiction of authority for air quality management granted to Metro Vancouver by the Province of British Columbia, it is useful to understand how this activity contributes to overall GHG emissions. For example Air travel by Metro Vancouver residents accounts for an additional $22 \%$ to $26 \%$ of GHG emissions, above what is already counted for on-road transportation in the regional emission inventory. Comparing the carbon eco-footprint of air travel by Metro Vancouver residents with that of other sectors could help to identify the most fruitful areas for emissions-reductions policy as well as areas for further research. In any case, the data should be available to Metro residents to improve their understanding of the need to reduce their personal ecological footprints and to underscore the importance of possible lifestyle changes.

Beyond illustrating the air travel implications for our case study region of Metro Vancouver, we have met our primary objective of developing methods for calculating the ecological footprint of air travel that are accessible to researchers, including urban planners, in other cities and regions. The confluence of climate change, ecological limits, peak oil and globalization affects cities and regions in complex ways. This paper underscores that air travel is an important impact factor that must be accounted for in consideration of regional sustainability. Limits to nature's capacity to absorb carbon dioxide emissions may well combine with declining fossil fuel reserves and may constrain opportunities for non-essential air travel in the future.

\section{Acknowledgements}

We appreciate the feedback provided by anonymous reviewers of this paper. We would like to thank the efforts of Cornelia Sussmann, PhD Candidate, School of Community and Regional Planning, University of British 
Columbia for preliminary research into how to tackle this research project. We also wish to acknowledge the financial contributions of the Canadian Social Sciences and Humanities Research Council, the Government of British Columbia Pacific Century Graduate Scholarship, and the Pacific Institute for Climate Solutions for financial contributions in support of this research.

\section{References}

Aall, C., \& Norland, I. (2005). The use of the ecological footprint in local politics and administration: Results and implications from Norway. Local Environment, 10, 159-172. http://dx.doi.org/10.1080/1354983052000330752

Air Broker Center International. (2009). Aircraft Charter World. Retrieved 2 November, 2010 from http://www.aircraft-charter-world.com

Airliners.net. (2010). Aircraft Stats. Retrieved 3 November, 2010 from http://www.airliners.net/aircraft-data/stats/

All Experts Encyclopedia. (2010). SH6 Mileage. Retrieved 14 November, 2010 from http://www.associatepublisher.com/

Barrett, J., Vallack, H., Jones, A., \& Haq, G. (2002). A material flow analysis and ecological footprint of York: Technical report. Stockholm: Stockholm Environment Institute.

BC Stats. (2010). Greater Vancouver Regional District: Community Facts (BC Stats: 250-387-0327). Victoria BC: BC Government Ministry of Citizens Services. Retrieved 24 August, 2010 from http://www.bcstats.gov.bc.ca/data/dd/facsheet/cf170.pdf

Benjamin, R. (2013). Assessing our environmental progress. The International Civil Aviation Organization

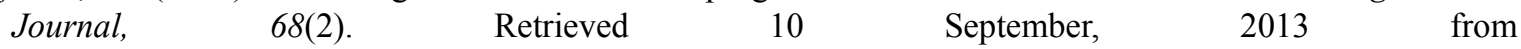
http://www.icao.int/publications/Pages/ICAO-Journal.aspx?year=2013\&lang=en

Berelowitz, L. (2005). Dream city: Vancouver and the global imagination. Vancouver: Douglas and McIntyre.

Chambers, N., Simmons, C., \& Wackernagel, M. (2001). Sharing nature's interest: Ecological footprints as an indicator of sustainability. London: Earthscan Publications.

City of Cardiff. (2012). Cardiff one planet city. Draft. Cardiff, UK: City of Cardiff. Retrieved 16 November, 2012 from http://www.cardiff.gov.uk/template/oneplanet/idea1/Oneplanetliving_eng.pdf

City of Vancouver. (2011). Greenest city 2020 action plan. Vancouver: City of Vancouver. Retrieved 18 April, 2012 from http://vancouver.ca/ctyclerk/cclerk/20110712/documents/rr1.pdf

Collins, A., Flynn, A., Wiedmann, T., \& Barrett, J. (2008). The environmental impacts of consumption at a subnational level-the ecological footprint of Cardiff. Journal of Industrial Ecology, 10, 9-23. http://dx.doi.org/10.1162/jiec.2006.10.3.9

Curry, R,. Maguire, C., Simmons, C., \& Lewis, K. (2011). The use of material flow analysis and the ecological footprint in regional policy-making: Application and insights from Northern Ireland. Local Environment, 16, 165-179. http://dx.doi.org/10.1080/13549839.2010.549118

Daggett, D., Hadaller, O., Hendricks, R., \& Walther, R. (2006). Alternative fuels and their potential impact on aviation. Prepared for the National Aeronautics and Space Administration (NASA) 25th Congress of the International Council of the Aeronautical Sciences (ICAS).

David Suzuki Foundation (DSF). (2010). Air travel and climate change. Vancouver, BC: David Suzuki Foundation. $\quad$ Retrieved 4 December, 2010 from http://www.davidsuzuki.org/issues/climate-change/science/climate-change-basics/air-travel-and-climate-cha nge/

Desai, P. (2008). Creating low carbon communities: One planet living solutions. Globalizations, 5, 67-71. http://dx.doi.org/10.1080/14747730701587462

Environment Canada. (2010). National inventory report: Greenhouse gas sources and sinks in Canada. $\begin{array}{llll}\text { Retrieved } & 2 & \text { November, } & 2010\end{array}$ http://www.ec.gc.ca/Publications/default.asp?lang=En\&xml=492D914C-2EAB-47AB-A045-C62B2CDAC $\mathrm{C} 29$

Ewing, B., Goldfinger, S., Oursler, A., Reed, A., Moore, D., \& Wackernagel, M. (2009). The ecological footprint atlas. Oakland, CA: Global Footprint Network. 
Ewing, B., Reed, A., Rizk, S. M., Galli, A., Wackernagel, M., \& Kitzes J. (2008). Calculation methodology for the national footprint accounts. Oakland, CA: Global Footprint Network.

Fiala, N. (2008). Measuring sustainability: Why the ecological footprint is bad economics and bad environmental science. Ecological Economics, 67, 519-525. http://dx.doi.org/10.1016/j.ecolecon.2008.07.023

Global Footprint Network. (2012). Footprint for Cities. Retrieved April 5, 2012 from http://www.footprintnetwork.org/en/index.php/GFN/page/footprint_for_cities/

Graymore, M., Sipe, N., \& Rickson, R. (2010). Sustaining human carrying capacity: a tool for regional $\begin{array}{lllll}\text { sustainability } & \text { assessment. } & \text { Ecological } & \text { Economics, } & 69,\end{array}$ http://dx.doi.org/10.1016/j.ecolecon.2009.08.016

Hall, C. A. S., \& Day, J. W. (2009). Revisiting the limits to growth after peak oil. American Scientist, 97, 230-237. http://dx.doi.org/10.1511/2009.78.230

Holden, E. (2004). Ecological footprints and sustainable urban form. Journal of Housing and the Built Environment, 19, 91-109. http://dx.doi.org/10.1023/B:JOHO.0000017708.98013.cb

Holden, M. (2006). Urban indicators and the integrative ideals of cities. Cities, 23, 170-83. http://dx.doi.org/10.1016/j.cities.2006.03.001

Hupe, J. (2013). Driving progress through action on aviation and environment. The International Civil Aviation Organization Journal, 68(2). Retrieved $10 \quad$ September, 2013 from http://www.icao.int/publications/Pages/ICAO-Journal.aspx?year=2013\&lang=en

Intergovernmental Panel on Climate Change (IPCC). (2001a). Aviation and the global atmosphere. Retrieved 25 February, 2011 from http://www.grida.no/publications/other/ipcc_sr/?src=/climate/ipcc/aviation/index.htm

Intergovernmental Panel on Climate Change (IPCC). (2001b). IPCC third assessment report: Climate change 2001: Working group I: The scientific basis. Chapter 3: The carbon cycle and the climate system. Prentice, IC, lead author. Retrieved 11 July, 2011 from http://www.grida.no/publications/other/ipcc_tar/

Intergovernmental Panel on Climate Change (IPCC). (2001c). Climate change: The scientific basis. Cambridge, UK: IPCC.International Travel Survey (2008). Canadian Resident Trips Abroad. Retrieved 2 November, 2010 from http://www.nesstar.com/

International Civil Aviation Organization (ICAO). (2011). Annual Report of the Council. Retrieved 16 September, 2013 from http://www.icao.int/publications/pages/publication.aspx?docnum=9975

International Energy Agency (IEA). (2010). World energy outlook. Retrieved 3 December, 2010 from http://www.worldenergyoutlook.org/

James, N., \& Desai, P. (2003). One planet living in the thames gateway: A WWF-UK one million sustainable homes campaign report. Surrey, UK: World Wide Fund for Nature.

Kayak Flight Finder. (2010). Flight Search. Retrieved 3 December, 2010 from http://www.kayak.co.uk/flights

Kitzes, J., \& Wermer, P. (2006). Technical memorandum: The carbon conversion factor in ecological footprint accounts: calculations and sources of variability. Oakland, CA: Global Footprint Network.

Kuzyk, L. (2011). Ecological and carbon footprint by consumption and income in GIS: Down to a census village scale. Local Environment, 16, 871-886. http://dx.doi.org/10.1080/13549839.2011.615303

Lewan, L., \& Simmons, C. (2001). The use of ecological footprint and biocapacity analyses as sustainability indicators for sub-national geographic areas: a recommended way forward. EUROCITIES, Ambiente. Italy: European Common Indicators Project.

McManus, P., \& Haughton, G. (2006). Planning with ecological footprints: A sympathetic critique of theory and practice. Environment and Urbanization, 18, 113-127. http://dx.doi.org/10.1177/0956247806063963

Metro Vancouver. (2005). Air quality management plan: Clean air, breath easy. Burnaby, BC: Greater Vancouver Regional District.

Metro Vancouver. (2006). Metro Vancouver's Generalized Land Use by Municipality. Retrieved June 3, 2011 from http://www.metrovancouver.org/about/statistics/Pages/KeyFacts.aspx

Metro Vancouver. (2007). Lower Fraser Valley air emissions inventory and forecast and backcast. Burnaby, BC: Greater Vancouver Regional District.

Muniz, I., \& Galindo, A. (2005). Urban form and the ecological footprint of commuting: The case of Barcelona. 
Ecological Economics, 55, 499-514. http://dx.doi.org/10.1016/j.ecolecon.2004.12.008

Newman, P., \& Jennings, I. (2008). Cities as sustainable ecosystems: Principles and practice. Washington, DC: Island Press.

Nijkamp, P., Rossi, E., \& Vindign, G. (2004). Ecological footprints in plural: A meta-analytic comparison of empirical results. Regional Studies, 38, 747-765. http://dx.doi.org/10.1080/0034340042000265241

OAG Aviation. (2010). Aircraft Statistics. Retrieved 29 November, 2010 from http://www.oag.com/northamerica/airlineandairport/aircraftstatistics.asp/

Pivo, G. (1996). Toward sustainable urbanization on mainstreet Cascadia. Cities, 13, 339-54. http://dx.doi.org/10.1016/0264-2751(96)00021-2

Quinn, T. (1996). Engineering conversion factors. University of Minnesota. Retrieved 15 February, 2011 from http://www.cmrr.umn.edu/ strupp/units.html

Rees, W. E. (2006). Ecological footprints and biocapacity: essential elements in sustainability assessment. In J. Dewulf, \& H. Van Langenhove (Eds.), Renewables-based technology: Sustainability assessment. Chichester, UK: John Wiley and Sons. http://dx.doi.org/10.1002/0470022442.ch9

Rees, W. E. (2008). Confounding integrity: humanity as dissipative structure. In L. Westra, K. Bosselmann, \& R. Westra (Eds.), Reconciling human existence with ecological integrity. London: Earthscan.

Rees, W. E. (2009). The ecological crisis and self-delusion: implications for the building sector. Building Research and Information, 37, 300-311. http://dx.doi.org/10.1080/09613210902781470

Rees, W. E. (2013). Ecological footprint. In S. Levin (Ed.), Encyclopedia of biodiversity (2nd ed.). London: Academic Press.

Research and Innovative Technology Administration (RITA). (2010). Transportation Statistics. Retrieved 23 November, 2010 from www.transtats.bts.gov

Scotti, M., Bondavalli, C., \& Bodini, A. (2009). Ecological footprint as a tool for local sustainability: The municipality of Piacenza (Italy) as a case study. Environmental Impact Assessment Review, 29, 39-50. http://dx.doi.org/10.1016/j.eiar.2008.07.001

Statistics Canada. (2006a). Air Passenger Origin and Destination. Canada-United States Report. Catalogue no. 51-205X. Table 3-21. Retrieved 2 November, 2010 from http://www.statcan.gc.ca/bsolc/olc-cel/olc-cel?catno=51-205-X\&lang=eng

Statistics Canada. (2006b). International Travel. Catalogue no. 66-201-X.

Transport Canada. (2006). Government Spending on Transportation: 2006 Annual Report. Retrieved 3 December, 2010 from http://www.tc.gc.ca/eng/policy/anre-menu.htm

Transportation Safety Board of Canada. (2010). DH3 Mileage. Retrieved 4 December, 2010 from http://www.tsb.gc.ca/

UK Department of Transport. (2010). Mileage for PAG Piper. Retrieved 27 November, 2010 from http://www.aaib.gov.uk/

Union of Concerned Scientists. (1992). World Scientists' Warning to Humanity. Retrieved 28 November, 2010 from http://www.ucsusa.org/about/1992-world-scientists.html

Van den Bergh, J., \& Verbruggen, H. (1999). Spatial sustainability, trade and indicators: An evaluation of the ecological footprint. Ecological Economics, 29, 61-72. http://dx.doi.org/10.1016/S0921-8009(99)00032-4

Vancouver International Airport Official (YVR) Website. (2010). YVR Passengers (Enplaned + Deplaned) 1992-2009. Retrieved 17 November, 2010 from: http://www.yvr.ca/en/about/facts-stats.aspx

Wackernagel, M., \& Monfreda, C. (2004). Ecological footprint and energy. Encyclopedia of Energy. Vol 2. http://dx.doi.org/10.1016/B0-12-176480-X/00120-0

Wackernagel, M., \& Rees, W. E. (1996). Our ecological footprint: Reducing human impact on the earth. Gabriola Island, BC: New Society Publishers.

Wackernagel, M., \& Rees, W. E. (1996). Our ecological footprint: Reducing human impact on the earth. Gabriola Island, BC: New Society Publishers.

Wackernagel, M. (2009). Methodological advances in footprint analysis. Ecological Economics, 68, 1925-1927. http://dx.doi.org/10.1016/j.ecolecon.2009.03.012 
Weidmann, T., Minx, J., Barrett, J., Vanner, R., \& Ekins, P. (2006). Sustainable consumption and production-development of an evidence base. Project Reference SCP001-Resource Flows. Department of Environment, Food and Rural Affairs (DEFRA). Retrieved from http://www.resource-accounting.org.uk/uploads/Reports/scp001.pdf

Wheeler, S., \& Beatley, T. (Eds.). (2009). The sustainable urban development reader (2nd ed.). London: Routledge, Taylor and Francis Group.

Wilson, J., \& Grant, J. (2009). Calculating ecological footprints at the municipal level: What is a reasonable approach for Canada? Local Environment, 14, 963-979. http://dx.doi.org/10.1080/13549830903244433

Wilson, M., \& Anielski, M. (2005). Ecological footprints of Canadian municipalities and regions. Ottawa: Federation of Canadian Municipalities. Retrieved 28 May, 2012 from http://www.fcm.ca/Documents/reports/Ecological_Footprints_of_Canadian_Municipalities_and_Regions_E N.pdf

World Airport Codes. (2010). Search distance between airports. Retrieved 13 November, 2010 from http://www.world-airport-codes.com/

Xu, S., \& San Martin, I. (2010). Ecological footprint for the twin cities: Impacts of consumption in the 7-county metro area. Minnesota: Metropolitan Design Centre, College of Design, University of Minnesota.

\section{Notes}

Note 1. YVR is not part of the GVTA.

Note 2. Exclusive because carbon sinks cannot generally be exploited for other purposes. For example, a commercial forest being harvested for wood/fibre is a source of carbon emissions, not a sink.

Note 3. YVR only provided data on number of flights and types of aircraft. All other information has come from industry references and other sources. The assumed $80 \%$ load factor was confirmed through correspondence with YVR to be a reasonable average to use in our calculation.

Note 4. Great Circle Distance measures the shortest route between two points on a sphere's surface (i.e. the Earth).

Note 5. There was not publicly available data on the actual number of passengers.

Note 6. An alternative to calculating total fuel consumed is calculating total amount of fuel loaded on outbound aircraft. In this study, we did not use total fuel loaded onto outbound aircraft because that data was unavailable.

Note 7. Here we refer to GHG equivalence only, not EF equivalence. EF is reserved for impacts that can be expressed in terms of ecosystem area (Methane cannot be expressed as such).

Note 8. Emission inventory year is 2005 .

Note 9. Consumption of biocapacity exceeds available 'income' in the form of local supply.

\section{Copyrights}

Copyright for this article is retained by the author(s), with first publication rights granted to the journal.

This is an open-access article distributed under the terms and conditions of the Creative Commons Attribution license (http://creativecommons.org/licenses/by/3.0/). 